\title{
Aplikasi Augmented Reality (AR) Alur Pembuatan SIM C Berbasis Android
}

\author{
Arif Supriyanto $^{1)}$, Asmilia ${ }^{2)}$ \\ 1)2) Jurusan Teknik Informatika, Politeknik Negeri Tanah Laut \\ 1) arif@politala.ac.id, 2) asmilia203@gmail.com
}

\begin{abstract}
Abstrak
Augmented Reality (AR) merupakan teknologi yang menggabungkan benda maya dua dimensi dan tiga dimensi lalu memproyeksikan benda-benda maya tersebut kedalam dunia nyata. Tujuan dari dibangunnya aplikasi AR alur pembuatan SIM C berbasis Android ini adalah untuk memberikan informasi yang yang lebih menarik dan interaktif kepada masyarakat tentang alur pembuatan SIM C. Melalui media informasi ini masyarakat dapat berinteraksi langsung dengan aplikasi AR untuk mengetahui alur pembuatan dan juga persyaratan pembuatan SIM C dengan lebih menarik dan mudah dimengerti. Aplikasi yang dibangun menampilkan objek virtual 3D dan audio pada perangkat mobile android secara real time. Berdasarkan hasil pengujian aplikasi ini dapat bekerja dengan baik pada mobile platform android dan hasil uji coba implementasi berdasarkan kuisioner sebanyak 30 orang menggunakan metode skala likert diperoleh hasil 80,66\%. Maka dapat disimpulkan aplikasi AR alur pembuatan SIM C berbasis android ini dikategorikan sangat baik.
\end{abstract}

Kata kunci: Augmented Reality, SIM C, Android, skala likert

\section{Abstract}

Augmented Reality (AR) is a technology that combines two-dimensional and three-dimensional virtual objects and projects these virtual objects into the real world. The purpose of the construction of the AR application for Android-based C SIM manufacturing is to provide more interesting and interactive information to the public about SIM C manufacturing flow. Through this information media the community can interact directly with the AR application to determine the manufacturing flow and also the SIM C manufacturing requirements. The application that is built displays $3 D$ virtual objects and audio on an Android mobile device in real time. Based on the results of testing this application can work well on the Android mobile platform and the results of implementation trials based on questionnaires as many as 30 people using the Likert scale method obtained $88 \%$ results. So it can be concluded that the AR application for making Android-based SIM C is categorized very well.

Keywords: Augmented Reality, SIM C, Android, Likert scale

\section{PENDAHULUAN}

Surat Izin Mengemudi (SIM) adalah bukti registrasi dan identifikasi yang diberikan oleh polri kepada seseorang yang telah memenuhi persyaratan administrasi, sehat jasmani dan rohani, memahami peraturan lalu lintas dan terampil mengemudikan kendaraan bermotor (Anam, 2017). Mekanisme pembuatan SIM di mulai dari tes kesehatan, setelah tes kesehatan selesai dilanjutakan registrasi diloket pendaftaran dengan melengkapi persyaratan fotokopi KTP dan surat keterangan kesehatan. Tahap berikutnya adalah ujian teori, ujian praktek dan dilanjutkan identifikasi. Tahap terakhir yaitu produksi SIM dilanjutkan dengan penyerahan SIM dan penyimpanan arsip dokumen registrasi, batas berlaku SIM yaitu 5 tahun di hitung dari pembuatan SIM. Setelah 5 tahun masa berlaku SIM, pemilik SIM wajib memperpanjang SIM tersebut dengan memenuhi syarat yaitu fotokopi KTP dan surat keterangan kesehatan Pembuatan SIM baru dan perpanjangan SIM dilakukan di Polres.

Berdasarkan hasil obeservasi di lapangan, kurangnya pemahaman dan pengetahuan tentang alur pembuatan SIM terutama SIM C membuat masyarakat kerap kali kebingungan dalam alur pembuatan SIM C baru maupun perpanjang, salah satunya tentang cara ujian atau tes apa saja yang akan di 
laksanakan untuk mendapatkan SIM C baru sehingga membuat masyarakat malas untuk membuat SIM $\mathrm{C}$ karena keterbatasan pengetahuan tentang alur pembuatan SIM C.

Augmented Reality (AR) merupakan teknologi yang menggabungkan benda maya dua dimensi dan tiga dimensi lalu memproyeksikan benda-benda maya tersebut kedalam dunia nyata. Pemanfaatan teknologi AR sebagai media informasi merupakan salah satu strategi pengenalan yang efektif.

Augmented Reality (AR) adalah kombinasi antara dunia maya (virtual) dan dunia nyata (real) yang dibuat oleh komputer. Objek virtual dapat berupa teks, animasi, model 3D atau video yang digabungkan dengan lingkungan sebenarnya sehingga pengguna merasakan objek virtual berada di lingkungannya (Fernando, 2013). Penggunaan AR saat ini telah banyak digunakan di berbagai aspek kehidupan.

Yudiantika dkk. (2013) menerapkan teknologi AR untuk menyediakan informasi benda-benda di dalam museum. AR yang digunakan terdiri dari AR Desktop dan AR Mobile. Berdasarkan hasil pengujian penggunaa AR Mobile lebih mempunyai keunggulan karena sifatnya yang mudah berpindah. Hermawan dan hariadi (2015) mengembangkan teknologi AR yaitu pemanfaatan AR sebagai media informasi kampus menggunakan media brosur, hasil pada penelitan ini dapat menunjukkan bahwa pembaca dapat melihat bagian brosur AR dengan lebih detil. Rusnandi dkk (2016) memanfaatkan teknologi AR sebagai media pembelajaran pemodelan bangun ruang untuk siswa sekolah dasar, pada penelitan ini menjelaskan materi pembelajaran berupa nama bangun dan rumus-rumusnya yang diproyeksikan kedalam bentuk 3D secara real-time.

Berdasarkan permasalahan di atas penulis mengangkat penelitian dengan membangun aplikasi AR untuk media informasi alur pembuatan SIM C berbasis android. Tujuan dibangunnya aplikasi AR ini adalah untuk menyediakan media informasi alur pembuatan SIM C dalam bentuk media dan digital bagi masyarakat umum dengan lebih menarik, interaktif dan mudah dimengerti.

Dalam membangun aplikasi AR diperlukan beberapa software pendukung seperti unity, vuforia SDK dan blender. Unity merupakan sebuah game engine yang digunakan untuk membuat dan membangun skenario, visualisasi game dan berbagai macam pemodelan multimedia interaktif. Vuforia SDK dikenal sebagai software development kit pengenalan gambar berbasis vision komputer dengan berbagai fitur. Vuforia dikhususkan untuk pembuatan aplikasi mobile, oleh vuforia kamera pada smartphone digunakan sebagai input layar pada smartphone digunakan sebagai output (Indriani dkk., 2016). Vuforia memerlukan beberapa komponen yang harus dimiliki agar dapat bekerja dengan baik. Komponen tersebut antara lain: kamera yang digunakan untuk menangkap setiap frame untuk diteruskan ke tracker, image converter yang digunakan untuk mengkonversi format kamera, tracker sebagai algoritma yang dapat mendeteksi dan melacak obyek dunia nyata, video background renderer yang digunakan untuk me-render gambar yang dihasilkan oleh kamera, aplication code mengeinisialisasi dan melakukan target deteksi marker serta update logika aplikasi setiap ada input baru dimasukkan, dan komponen yang terakhir adalah target resources dibuat menggunakan online target management system yang memungkinkan developer untuk mengkonfirgurasi beberapa fitur. Sedangkan blender merupakan software open source yang multiplatform digunakan untuk membuat konten digital khususnya obyek $3 \mathrm{D}$.

\section{METODE PENELITIAN}

Dalam penelitian ini peneliti menggunakan metode penelitian sebagai berikut:

\section{Dokumentasi}

Dokumentasi dilakukan untuk mengumpulkan data dan informasi yang diperlukan dalam pembuatan aplikasi AR alur pembuatan SIM C, proses pengumpulan data dilakukan dengan melakukan wawancara secara langsung kepada petugas Satlantas Polisi Resort Tanah Laut dan kepada masyarakat umum yang berada di lokasi pembuatan SIM C sebanyak 30 orang .

\section{Kepustakaan}

Studi pustaka dilakukan untuk mendapatkan konsep-konsep teoritis, kepustakaan dilakukan dengan cara menganalisa data pada literatur dan media lain yang dapat membantu dalam pemecahan masalah.

\section{Perancangan}

Perancangan sistem menggunakan DFD dan flowchart, software yang digunakan untuk membangun aplikasi AR adalah Unity, Vuforia, Blender.

\section{Implementasi}


Aplikasi AR sebagai media informasi alur pembuatan SIM C pada perangkat mobile smartphone berbasis android.

\section{Kuisioner}

Kuisioner ini disusun dalam bentuk pertanyaan untuk mengumpulkan data tanggapan pengguna terhadap aplikasi AR yang telah dibangun dengan jumlah responden sebanyak 30 orang.

\section{Observasi}

Metode ini digunakan untuk mendapatkan hasil uji coba fungsionalitas dari aplikasi AR menggunakan metode black box tersting yang mengevaluasi hanya dari interface dan mengetahui input dan output dari aplikasi AR alur pembuatan SIM berbasis android.

\section{HASIL DAN PEMBAHASAN}

\section{Rancangan Alur Sistem}

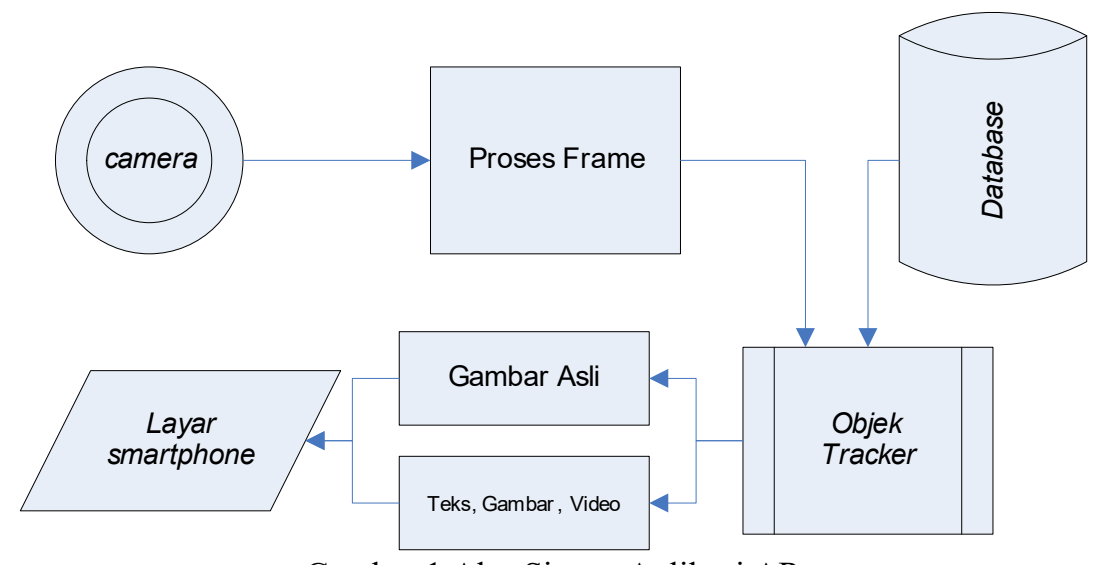

Gambar 1 Alur Sistem Aplikasi AR

Gambar 1 menggambarkan alur sistem dari aplikasi AR yang akan dibangun, tahap pertama dimulai dari pengambilan atau capture marker dengan menggunakan kamera smartphone. Marker dikenali berdasarkan fitur yang dimiliki kemudian masuk ke dalam tahap berikutnya yaitu object tracker yang telah disediakan oleh Software Development Kit. Marker tersebut telah didaftarkan dan disimpan ke dalam database. Tahap berikutnya object tracker selanjutnya akan melacak dan mencocokkan marker tersebut agar dapat menampilkan informasi yang sesuai. Informasi alur pembuatan SIM C akan segera ditampilkan secara real time kedalam layar smartphone.

\section{Implementasi Sistem}

Aplikasi AR alur pembuatan SIM C ini terdiri dari dua halaman, halaman yang pertama terdiri dari splash screen atau halaman awal dari aplikasi setelah aplikasi dijalankan. Halaman berikutnya yaitu halaman menu, halaman menu muncul setelah beberapa detik dari halaman splash screen. Halaman menu menampilkan 5 buah menu yaitu: menu SIM C, menu undang-undang yang menampilkan seputar undang-undang lalu lintas, menu profil menampilkan profil dari polisi satlantas, menu petunjuk menampilkan tata cara, petunjuk penggunaan aplikasi AR yang menjelaskan bagaiman cara mengarahkan kamera yang terdapat pada smartphone ke marker dan menu keluar. Pada menu SIM C terdapat dua buah menu yang memberikan informasi alur pembuatan SIM C yang diproyeksikan kedalam obyek 3D, kedua menu ini antara lain: menu SIM C Baru dan menu SIM C Perpanjangan. Hasil dari halaman menu SIM C Baru dapat dilihat pada Tabel 1. 
Tabel 1. Menu SIM C Baru

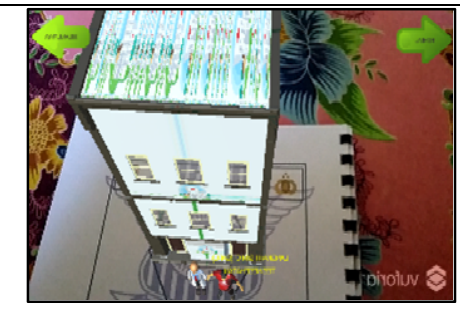

Langkah 1 Tes Kesehatan (Gambar Aplikasi AR Alur Pembuatan SIM)

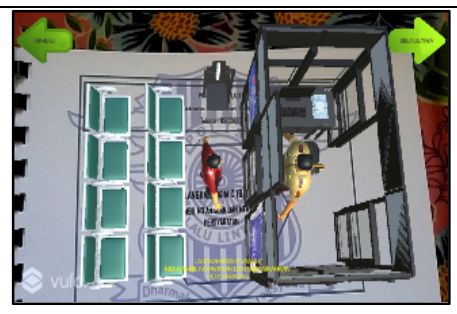

Langkah 2 Mengambil No Antrian dan Menyerahkan

Persyaratan SIM C (Gambar Aplikasi AR Alur Pembuatan SIM)

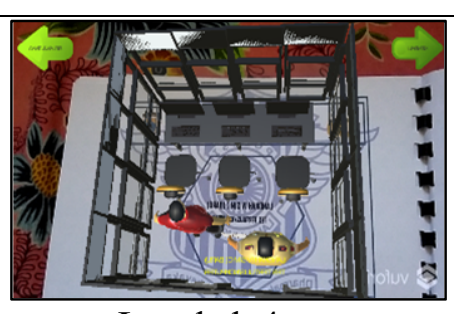

Langkah 4 Tes

Tertulis/Komputer (Gambar Aplikasi AR Alur Pembuatan SIM)

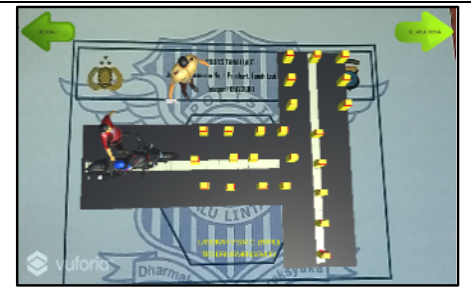

Langkah 5 Tes

Drive/Mengemudi (Gambar Aplikasi AR Alur Pembuatan SIM)

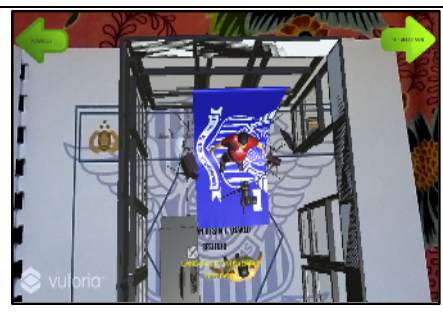

Langkah 3 Sesi Foto (Gambar Aplikasi AR Alur Pembuatan SIM)

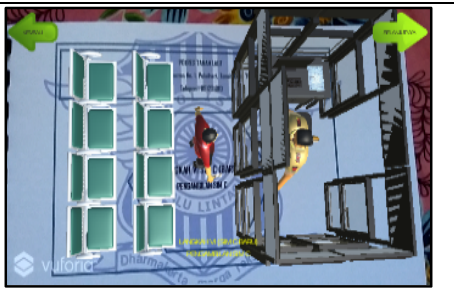

Langkah 6 Pengambilan SIM (Gambar Aplikasi AR Alur Pembuatan SIM)

\section{Tabel 2. Menu SIM C Perpanjangan}

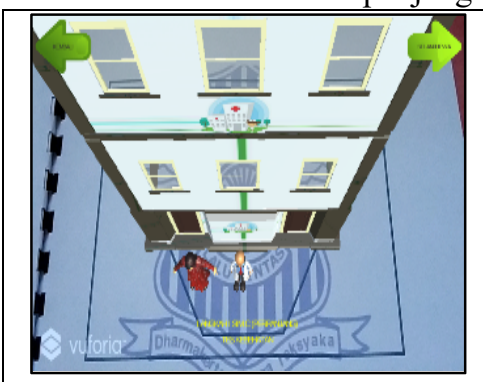

Langkah 1 Tes Kesehatan (Gambar Aplikasi AR Alur Pembuatan SIM)

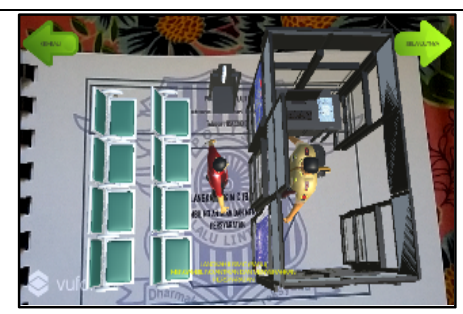

Langkah 2 Mengambil No Antrian dan Menyerahkan

Persyaratan SIM C

(Gambar Aplikasi AR Alur Pembuatan SIM)

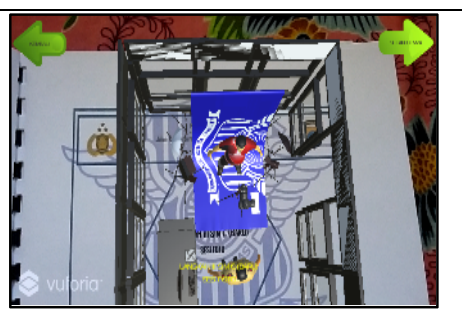

Langkah 3 Sesi Foto (Gambar Aplikasi AR Alur Pembuatan SIM)

Tabel 1 dan Tabel 2 menjelaskan langkah-langkah pembuatan SIM C baru dan perpanjangan, semua obyek 3D yang ditampilkan pada aplikasi AR ini dapat dilakukan rotasi obyek sehingga memudahkan pengguna aplikasi untuk melihat obyek 3D secara lebih detil, kemudian di setiap obyek juga terdapat informasi berupa audio yang menjabarkan persyaratan atau hal-hal apa saja yang harus dilakukan oleh pengguna disetiap langkah proses pembuatan SIM C baru maupun perpanjangan.

\section{Pengujian Sistem}

Pada pengujian sistem menggunakan smartphone Samsung J7 duo, dengan spesifikasi sebagai berikut:

1. Prosessor Octa-Core $(2 \times 2.2 \mathrm{GHz}$ Cortex-A73 \& $6 \times 1.6 \mathrm{GHz}$ Cortex-A53)

2. RAM $3 \mathrm{~GB}$, Storage $32 \mathrm{~GB}$

3. Android 8.0 (Oreo)

4. Kamera utama: $13 \mathrm{MP}+5 \mathrm{MP}$

5. Layar 5.5 Inc Super AMOLED Capacitive Touchscreen

Pengujian dilakukan dengan metode black box hasil pengujian dapat dilihat pada Tabel 3. 
Tabel 3. Hasil Pengujian Aplikasi AR Alur Pembuatan SIM C

\begin{tabular}{|c|l|l|c|}
\hline No & \multicolumn{1}{|c|}{ Kasus uji } & \multicolumn{1}{|c|}{ Hasil yang diharapkan } & Hasil pengujian \\
\hline 1 & Install APK & Aplikasi terinstall pada smartphone android & Berhasil \\
\hline 2 & Running Aplikasi & $\begin{array}{l}\text { Aplikasi memunculkan halaman splash screen } \\
\text { kemudian dilanjutkan ke menu utama }\end{array}$ & Berhasil \\
\hline 3 & Pilih menu petunjuk & Menampilkan halam petunjuk penggunaan & Berhasil \\
\hline 4 & $\begin{array}{l}\text { Pilih menu undang- } \\
\text { undang }\end{array}$ & $\begin{array}{l}\text { Menampilkan informasi tentang undang-undang } \\
\text { lalu lintas }\end{array}$ & Berhasil \\
\hline 5 & Pilih menu profil & Menampilkan profil satuan satlantas & Berhasil \\
\hline 6 & Pilih menu SIM Baru & Muncul tampilan untuk menangkap marker & Berhasil \\
\hline 7 & $\begin{array}{l}\text { Pilih menu SIM } \\
\text { Perpanjangan }\end{array}$ & Muncul tampilan untuk menangkap marker & Berhasil \\
\hline 8 & $\begin{array}{l}\text { Capture marker SIM } \\
\text { Baru }\end{array}$ & Menampilkan obyek 3D dan informasi audio & Berhasil \\
\hline 9 & $\begin{array}{l}\text { Caputer marker SIM } \\
\text { Perpanjangan }\end{array}$ & Menampilkan obyek 3D dan informasi audio & Berhasil \\
\hline 10 & Pilih menu keluar & Keluar dari aplikasi AR & \\
\hline
\end{tabular}

\section{Hasil Kuisioner}

Kuisioner dilakukan dengan cara memberikan selebaran berupa pertanyaan yang mengarah kepada apakah aplikasi AR ini dapat membantu dan memudahkan masyarakat dalam memahami alur pembuatan SIM C baru atau SIM C Perpanjangan.

Kuisioner dilakukan dengan menggunakan metode skala likert terhadap 30 responden, dengan hasil sebagai responden dapat dilihat pada tabel 4:

Tabel 4. Hasil pengujian responden

\begin{tabular}{|c|c|c|c|c|}
\hline No & Likert scale & Responden (T) & Score Likert $(\mathrm{Pn})$ & T x Pn \\
\hline 1 & Sangat Setuju (SS) & 18 orang & 5 & 90 \\
\hline 2 & Setuju (S) & 2 orang & 4 & 8 \\
\hline 3 & Netral (N) & 4 orang & 3 & 12 \\
\hline 4 & Tidak Setuju (TS) & 5 orang & 2 & 10 \\
\hline 5 & Sangat Tidak Setuju & 1 orang & 1 & 1 \\
\hline \multicolumn{2}{|c|}{ Total Score } \\
\hline
\end{tabular}

Interpretasi skor Perhitungan terdiri dari $(\mathrm{Y})$ yaitu Score tertinggi Likert $\mathrm{x}$ Jumlah responden $=5 \mathrm{x} 30$ $=150$ dan $(\mathrm{X})$ yaitu Score terendah Likert $\mathrm{x}$ Jumlah responden $=1 \mathrm{x} 30=30$.

\section{Interval Score :}

- Angka $0 \%-19,99 \%=$ Sangat Tidak Baik

- Angka $20 \%-39,99 \%$ = Kurang baik

- Angka $40 \%-59,99 \%$ = Netral

- Angka $60 \%-79,99 \%=$ Baik

- Angka $80 \%-100 \%=$ Sangat Baik

Penyelesaian akhir $=$ Total skor $/$ Y $\mathbf{x} 100$

$121 / 150 \times 100=80,66 \%$

Berdasarkan hasil perhitungan penyelesaian akhir diperoleh persentase sebesar $80,66 \%$ yang berati aplikasi AR yang sudah dibangun masuk didalam interval score Sangat Baik.

Hasil score menunjukkan bahwa aplikasi AR yang telah dibangun mudah untuk digunakan dan informasi tentang alur pembuatan SIM C menjadi lebih menarik dan mudah untuk dipahami sehingga masyarakat tidak kebingungan untuk membuat atau memperpanjang SIM C karna informasi yang didapatkan dari aplilkasi AR alut pembuatan SIM C sudah lengkap dan jelas. 


\section{KESIMPULAN}

1. Berdasarkan hasil kuisioner dari 30 responden aplikasi AR ini sangat baik dan dapat membantu dalam memberikan informasi tentang alur pembuatan SIM C dan informasi yang didapatkan mudah untuk dimengerti.

2. Telah berhasil dirancang dan dibangun aplikasi AR alur pembuatan SIM C sebagai media informasi alur pembuatan SIM C berbasis android.

3. Berdasarkan hasil pengujian sistem aplikasi AR ini dapat berjalan dengan baik.

\section{DAFTAR PUSTAKA}

Anam, A. S., Wardhani, R., \& Masruroh, M. (2017). Aplikasi Simulasi Membuat Sim C Berbasis Android. Jurnal Teknika, 9(2), 8 .

Hermawan, L., \& Hariadi, M. (2015). Pemanfaatan Augmented Reality Sebagai Media Informasi Kampus Menggunakan Brosur. In Seminar Nasional Teknologi Informasi dan Komunikasi (SENTIKA) Yogyakarta (Vol. 28).

Indriani, R., Sugiarto, B., \& Purwanto, A. (2016). Pembuatan Augmented Reality Tentang Pengenalan Hewan untuk Anak Usia Dini Berbasis Android Menggunakan Metode Image Tracking Vuforia. SEMNASTEKNOMEDIA ONLINE, 4(1), 4-7.

Rusnandi, E., Sujadi, H., \& Fauzyah, E. F. N. (2016). Implementasi Augmented Reality (AR) pada Pengembangan Media Pembelajaran Pemodelan Bangun Ruang 3D untuk Siswa Sekolah Dasar. INFOTECH journal, 1(2).

Yudiantika, A. R., Pasinggi, E. S., Sari, I. P., \& Hantono, B. S. (2013). Implementasi Augmented Reality Di Museum: Studi Awal Perancangan Aplikasi Edukasi Untuk Pengunjung Museum. Yogyakarta: Konferensi Nasional Teknologi Informasi dan Komunikasi (KNASTIK), Fakultas Teknologi Informasi, Universitas Kristen Duta Wacana.

\section{Biodata Penulis}

Arif Supriyanto, lahir di Pelaihari pada tanggal 27 September 1989. Penulis kedua memperoleh gelar sarjana Teknik Iformatika (S.Kom) di STMIK Indonesia Banjarmasin dan menyelesaikan sastra 2 Master of Computer Science (M.Cs) di Program Studi Ilmu Komputer dari Universitas Gadjah Mada. Setelah memperoleh gelar Magister, penulis bekerja menjadi Dosen di Jurusan Teknik Informatika Politeknik Negeri Tanah Laut mulai tahun 2017.

Asmilia, lahir di Kandangan Baru pada tanggal 17 November 1998. Penulis pertama menyelesaikan Sekolah Menengah Atas di SMKN 1 Pelaihari pada Tahun 2015 dan melanjutkan pendidikan ke Politeknik Negeri Tanah Laut. 